OPEN ACCESS

Edited by:

Thomas M. Davis,

University of New Hampshire,

United States

Reviewed by:

Hamid Khazaei,

University of Saskatchewan, Canada

Tomas Vymyslicky,

Agricultural Research, Ltd., Czechia

${ }^{*}$ Correspondence: lain R. Searle

iain.searle@adelaide.edu.au

Specialty section:

This article was submitted to

Plant Breeding,

a section of the journal

Frontiers in Plant Science

Received: 27 February 2020

Accepted: 21 May 2020

Published: 19 June 2020

Citation:

Nguyen V, Riley S, Nagel S, Fisk and Searle IR (2020) Common Vetch:

A Drought Tolerant, High Protein

Neglected Leguminous Crop With

Potential as a Sustainable Food

Source. Front. Plant Sci. 11:818.

doi: 10.3389/fpls.2020.00818

\section{Common Vetch: A Drought Tolerant, High Protein Neglected Leguminous Crop With Potential as a Sustainable Food Source}

\author{
Vy Nguyen ${ }^{1,2}$, Samuel Riley ${ }^{1,2}$, Stuart Nagel $^{3}$, lan Fisk ${ }^{4}$ and lain R. Searle ${ }^{1,2 *}$ \\ 'School of Biological Sciences, School of Agriculture, Food and Wine, The University of Adelaide, Adelaide, SA, Australia, \\ ${ }^{2}$ Shanghai Jiao Tong University Joint International Centre for Agriculture and Health, The University of Adelaide, Adelaide, \\ SA, Australia, ${ }^{3}$ South Australian Research and Development Institute, Adelaide, SA, Australia, ${ }^{4}$ Division of Food Science, \\ Nutrition and Dietetics, School of Biosciences, University of Nottingham, Nottingham, United Kingdom
}

Global demand for protein is predicted to increase by $50 \%$ by 2050 . To meet the increasing demand whilst ensuring sustainability, protein sources that generate low-greenhouse gas emissions are required, and protein-rich legume seeds have the potential to make a significant contribution. Legumes like common vetch (Vicia sativa) that grow in marginal cropping zones and are drought tolerant and resilient to changeable annual weather patterns, will be in high demand as the climate changes. In common vetch, the inability to eliminate the $\gamma$-glutamyl- $\beta$-cyano-alanine (GBCA) toxin present in the seed has hindered its utility as a human and animal food for many decades, leaving this highly resilient species an "orphan" legume. However, the availability of the vetch genome and transcriptome data together with the application of CRISPR-Cas genome editing technologies lay the foundations to eliminate the GBCA toxin constraint. In the near future, we anticipate that a zero-toxin vetch variety will become a significant contributor to global protein demand.

\footnotetext{
Keywords: legume, common vetch, Vicia sativa, vetch toxin, $\gamma$-glutamyl- $\beta$-cyano-alanine, plant-based protein, sustainable
}

\section{INTRODUCTION}

Global demand for protein is predicted to increase by a staggering $50 \%$ by 2050 (Westhoek et al., 2011; Henchion et al., 2017). With an increasing global population and increasing demand for animal-derived protein, the sustainability of agriculture systems has been brought into question. Over the last two centuries, the expanding livestock industry has led to significant deforestation, and overgrazing of natural grassland environments such that it has caused decreased terrestrial biodiversity and increased greenhouse gas emissions and contributed to climate change and global warming (Henchion et al., 2017). In order to meet the increasing protein demand and protect our environment, more sustainable protein food sources are required. Cheap plant-based protein, such as legume seeds, represent an environmentally sustainable option that is well suited for developing countries with rapidly growing populations (Asgar et al., 2010). Moreover, to cope with increasingly unpredictable climate change and expansion of marginal cropping areas, breeding strategies for 
more drought tolerant and resilient crops will be vital (Sivakumar et al., 2005; Lobell and Gourdji, 2012). A legume that could be exploited for this scenario is the common vetch ( $V$. sativa). Common vetch is able to grow in marginal cropping zones whilst being resilient to variable annual weather patterns mainly through superior drought tolerance (White et al., 2005). One study demonstrated that vetch could withstand water deficit for up to 24 days and show full restoration of biotic function once regular watering had resumed (Tenopala et al., 2012). Drought and heat tolerant crops are increasingly desirable in the face of rising global temperatures and increasingly prolonged periods of drought brought on by climate change (Mba et al., 2018).

For many decades, the inability to remove the $\gamma$-glutamyl$\beta$-cyano-alanine (GBCA) seed toxin has hindered common vetch's use in agriculture (Pfeffer and Ressler, 1967; Roy et al., 1996) leaving this resilient plant as an "orphan" legume. We envisage that the development of a zero-toxin vetch variety would facilitate its use for animal feed, specifically chickens and pigs, and human consumption (Ressler et al., 1997; Collins et al., 2002). We estimate the production costs of common vetch are approximately $50 \%$ less than competing legumes such as lentils and predict that zero-toxin varieties would rapidly surpass lentil in pig and poultry production. Zero-toxin common vetch will immediately generate new domestic markets, such as feed for the poultry industry, but it will also open new export markets for Australia and other countries thereby increasing export revenue and increasing farm profitability and indirectly increase investment for their local communities.

\section{COMMON VETCH: A VERSATILE PASTURE CROP THAT PROVIDES MULTIPLE BENEFITS FOR THE FARM}

Common vetch ( $V$. sativa) which is shown in Figure $\mathbf{1}$ belongs to the Fabaceae (legume) family, within the genus Vicia. This genus contains about 140 species including woolly-pod vetch ( V. villosa) and faba bean ( $V$. faba). Other Fabaceae genera also contain so-called vetches; of which two examples are Astragalus (containing the milkvetches) and Lathyrus (containing L. ochrus, the cyprus-vetch). Nowadays, common vetch is commonly found both in natural and agricultural settings across Europe, Asia, North America, some parts of South America, Africa, the Mediterranean, and Australia (Navrátilová et al., 2003; Ford et al., 2008).

Like other legumes, common vetch forms a symbiosis with nitrogen-fixing bacteria (Rhizobia) that fix atmospheric nitrogen into nitrogenous compounds available to the plant, hence reducing the need for application of expensive nitrogen fertilizer and subsequent rotation crops. Often, common vetch is used as a green manure which, when incorporated into the soil, provides valuable carbon, and nitrogen for rotation crops such as wheat and barley. Additional soil carbon often increases water-holding capacity and ability to bind nutrients including nitrate (Reeves, 1997; Bünemann et al., 2018). Furthermore, common vetch biomass can also be used for forage, fodder, pasture, silage, or hay and the seed may safely be used as a protein-rich feed component for ruminant animals (Enneking, 1995). Common vetch is well suited as a pasture species as it forms many adventitious shoots that are either buried or close to the soil surface thus giving it the ability to be resilient to heavy grazing (Rathjen, 1997).

Despite common vetch's versatile uses, the production of vetch is still limited. Data collected by the Food and Agriculture Organization (FAO) in 2017 showed that, globally, the area harvested and the production of vetch were about 0.6 million ha and 0.9 million tons, respectively ${ }^{1}$. Based on FAO 2017 data for legumes, vetch occupied about $0.3 \%$ of land usage and accounted for only $0.2 \%$ of the production. This is 12 times less than the area harvested and 8 times less than the production of lentils (Figure 2). Common vetch's limited production is mainly attributed to the anti-nutritional compounds existing in the seeds which will be further discussed in the next section.

\section{COMMON VETCH SEEDS: IMPORTANT NUTRITIONAL ATTRIBUTES}

Common vetch seed appeared in the diets of hunter-gatherers as early as 12,000-9,000 BP as evident in archaeobotanical analysis of samples from the Santa Maira cave in Alicante, Spain (Aura et al., 2005; Mikić, 2016). Today, common vetch is globally distributed and its spread is thought to have occurred through the inadvertent selection and trading of vetch seeds as a weedy contaminant with other legume seeds (Erskine et al., 1994). This has led to the suggestion that selection of common vetch amongst other palatable legumes, such as lentils, led to vegetative, and seed mimicry of vetch to lentils (Erskine et al., 1994). Although intact lentil and vetch seed can be differentiated after close examination of the seed shape and size, the split seed is harder to distinguished. Due to the similarity of split vetch and lentil seeds, there was a period of time when split vetch seeds of the variety "Blanchefleur" were oil coated and inappropriately substituted and sold as lentils. However, Tate and Enneking (1992) raised the so-called substitution issue of vetch toxicity and indicated that vetch seeds were unsuitable to be eaten by monogastric animals, including humans. Since then, vetch has been restricted to use in pastures as the seeds can be safely eaten by ruminants and some monogastric animals, such as chicken (less than $40 \% \mathrm{w} / \mathrm{w}$ ), and pig (less than $20 \% \mathrm{w} / \mathrm{w}$ ) in low amounts (Rathjen, 1997).

Common vetch exhibits high concentrations of crude protein $(\mathrm{w} / \mathrm{w})$ in the seed between 24 to $32 \%$ (Francis et al., 2000). This concentration is comparable to faba bean ( $V$. faba) and lupin (Lupinus angustifolius L.) seed which have about 32\% (Crépon et al., 2010; Caliskanturk et al., 2017) and 30\% crude protein (Valentine and Bartsch, 1996), respectively. Common vetch seeds contain eighteen amino acids and the ratio of essential amino acids/non-essential amino acids is about 0.7 (Mao et al., 2015) which is significantly higher than the 0.38 recommended by WHO (Joint, 2007). Additionally, the principle essential amino acids are arginine and leucine at average concentrations of 2.4 and $2.1 \%$, respectively. Glutamic and aspartic acids are the

\footnotetext{
${ }^{1}$ http://www.fao.org/faostat/en/\#data
} 


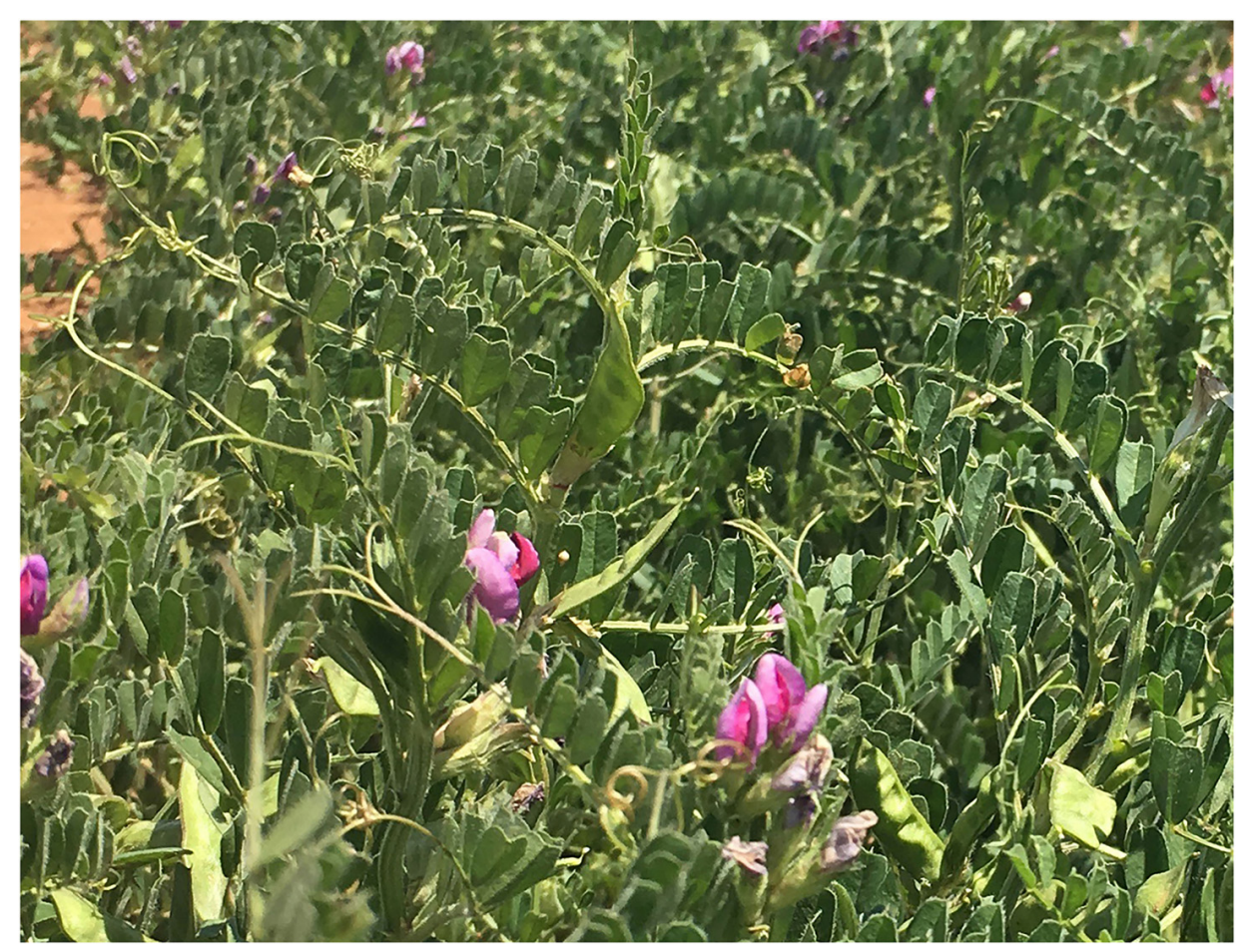

FIGURE 1 | Field grown Vicia sativa growing at the National Vetch Breeding Program in South Australia.

predominant non-essential amino acids within common vetch seed, averaging levels of 5.5 and 3.7\%, respectively (Mao et al., 2015). Vetch seed also contains a much lower proportion of lipids (only $1.5-2.7 \%$ ) compared with soybean seed (Glycine $\max$ ) and this is primarily composed of unsaturated fatty acids (Mao et al., 2015).

Presently, common vetch is mainly used as animal feed for ruminants and it can be argued that higher value returns could be observed through the repurposing of common vetch as a human food crop. Obstructing the development of the higher value product is a range of anti-nutritional factors, the most significant of which are the dipeptide GBCA and the free amino acid $\beta$-cyano-L-alanine (BCA), which exist in relatively high concentrations in the seed at approximately 2.6 and $0.9 \%$, respectively (Tate et al., 1999). Such compounds are toxic to monogastric species, such as chickens or pigs, but have no obvious effect upon ruminant species, including beef cattle (Valentine and Bartsch, 1996). The proportion (w/w) of common vetch seed within feeds that can be safely consumed without deleterious effects is $10 \%$ for piglets and $20 \%$ for adult pigs and for chickens about 40\% (Harper and Arscott, 1962; Rathjen, 1997). In addition to the main toxin GBCA, other anti-nutritional compounds were also found in common vetch included vicianine, vicine, convicine, and tannins (Ritthausen and Kreusler, 1870; Rathjen, 1997).

Genetic variation and relatively high heritability of vicianine levels in common vetch accessions have allowed breeders to select and produce cultivars free of this toxin. One early developed cultivar with no vicianine was Blanchefluer (Delaere, 1996;
Rathjen, 1997). Most modern common vetch cultivars are vicianine free. Vicine and convicine are well-studied in faba bean, and in humans cause the potentially fatal disease favism (Bottini, 1973). Vicine and convicine are hydrolysed by native $\beta$-glucosidases in the cotyledons of seeds to form divicine and isouramil and when consumed by humans can cause oxidation of glutathione in red blood cells. In individuals who cannot generate glutathione at normal rates due to a deficient glucose6-phophatedehydrogenase activity this results in haemolysis and the disease favism (Arese et al., 1981). Unlike vicianine and vicine, wild accessions and breeding lines with very low GBCA levels have not been identified, and the GBCA toxin levels in current cultivars is still deemed to be too high for monogastric consumption. Chickens can only tolerate feed with less than $20 \%$ (w/w) common vetch ( $\sim 0.2 \%$ GBCA in the feed). Confounding toxic effects of other compounds with vicine and GBCA were proposed (Rathjen, 1997), however, the chemical basis of these compounds is currently unknown. Finally, antinutritional tannins present in vetch seed coats are often removed during the dehulling process and hence are considered less significant (Rathjen, 1997).

\section{LIMITATION OF GBCA DETOXIFICATION USING CONVENTIONAL METHODS}

Without the toxic compounds in the seeds, vetch would be highly nutritious and a valuable animal feed. Therefore, a number of methods have been investigated to remove the toxins, mainly 


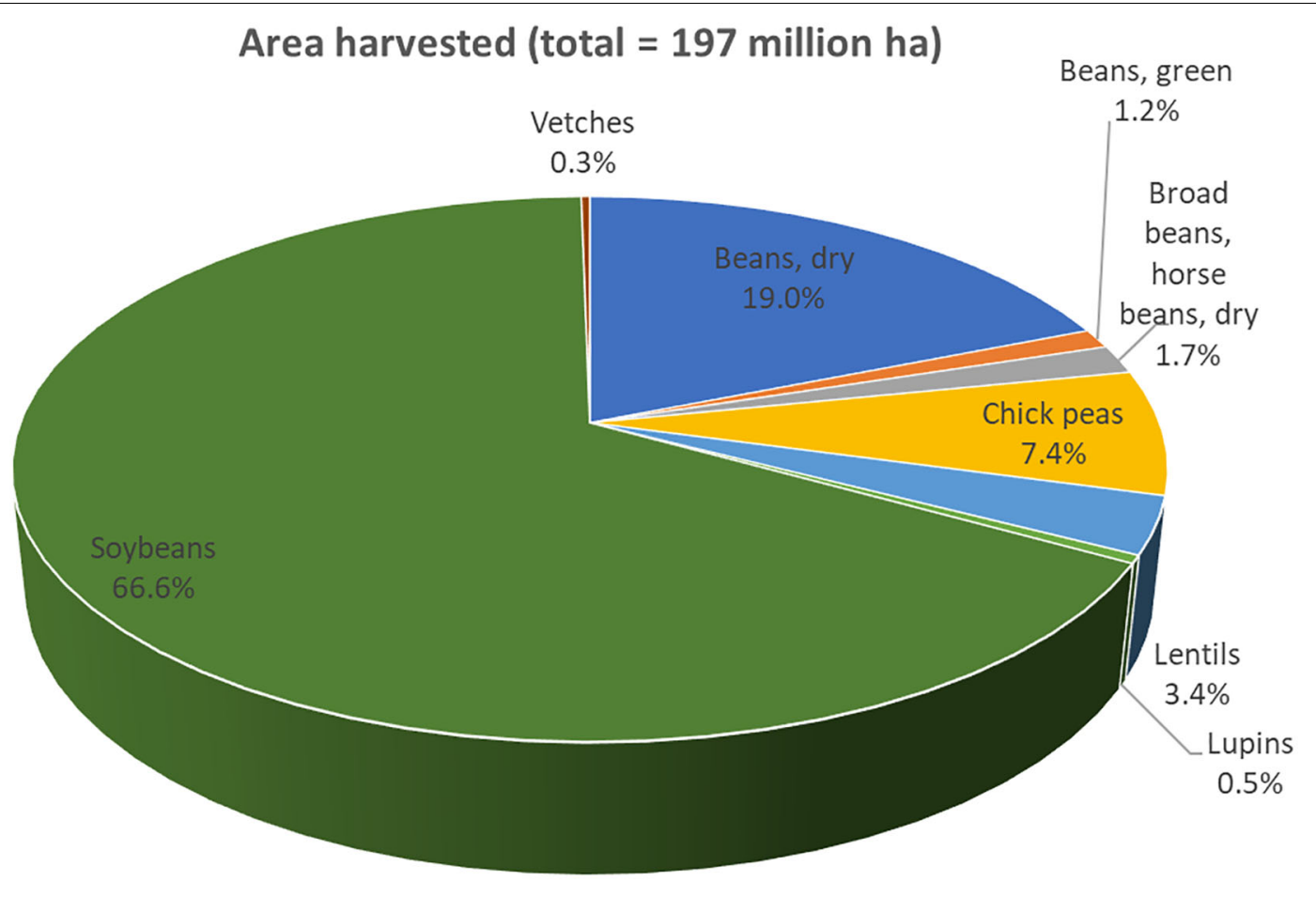

\section{Production (total $=474$ million tonnes)}

Broad beans, horse beans,

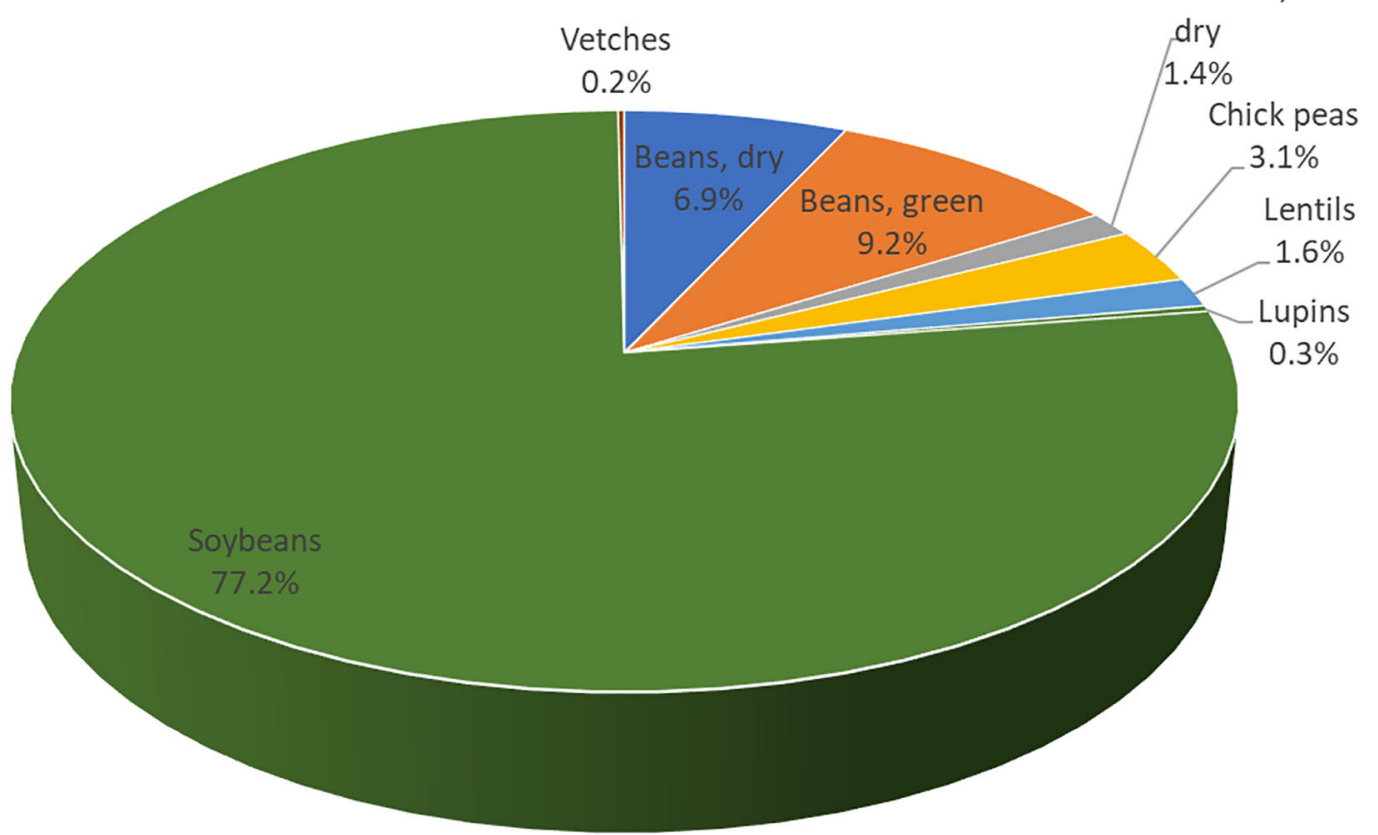

FIGURE 2 | Common vetch production when compared to other legumes globally in 2017. In general, common vetch occupied about $0.3 \%$ of the area harvested and $0.2 \%$ of the production. For vetch, total area harvested in 2017 was 560,077 ha and total production was 920,536 tons. Data was published by the Food and Agriculture Organization (FAO; http://www.fao.org/).

focusing on GBCA. Post-harvest processing efforts to lower the GBCA toxin levels within the seed have previously involved simple soaking, continuous flow through soaking, and boiling methods (Rathjen, 1997). The seed soaking method alone was insufficient to lower GBCA levels as consumption of soaked seed during feeding trials by chickens reduced egg production, and 
daily food consumption and feed conversion ratios were also diminished (Farran et al., 1995). In contrast, the boiling method reduced the toxin levels in the seed such that the seed could be included in chicken feed at levels of up to $25 \%$ without negative effects on growth rates (Kaya et al., 2013). However, consumption of boiled vetch seed that had the broth periodically discarded during boiling resulted in $20 \%$ reduced growth rates in chickens when compared with conventional feed with similar protein amounts (Ressler et al., 1997). This boiling method combined with periodically discarded water had $45 \%$ decreased seed mass as water soluble vitamins, like vitamin $B$, water soluble proteins and carbohydrates were leached during processing (Ressler et al., 1997), and this correlated with the reduced chick growth rate. Autoclaving the seed as a processing method has also been investigated and assessed in feeding trials of laying hens. In the laying hen trial, overall growth rate was found not significantly different between animals fed with autoclaved or raw vetch seed suggesting that the non-heat labile toxins like GBCA were still bioactive (Farran et al., 1995). The lack of success of these seed processing methods in improving animal growth or health has strongly indicated the need for genetic approaches to detoxify the common vetch seeds.

\section{UNSUCCESSFUL SEARCHES FOR ZERO-TOXIN VETCH ACCESSIONS}

Using conventional breeding methods and more recently the use of molecular marker-assisted breeding for genomic selection, plant breeders have prioritized the search for common vetch varieties that have biotic and abiotic stress resistant traits as well as selecting for increasing yield and seed nutritional quality (Francis et al., 2000). However, no concerted effort has been made to select for low or zero GBCA toxin levels in Australian or overseas breeding programs. This has resulted in varieties that are only used by farmers for pasture, green or brown silage, or ruminant feed (Francis et al., 2000; Dong et al., 2019; Huang et al., 2019; Mikić et al., 2019). This is mainly due to very limited natural variation in GBCA toxin levels amongst common vetch accessions (Rathjen, 1997). Rathjen (1997) screened over 1,700 $V$. sativa accessions and failed to identify a single accession with no GBCA toxin. Later, screening of a total of 3,000 accessions identified only one line, IR28, with a low (0.3-0.4\%) GBCA level but no zero-toxin line has yet been identified (Ford et al., 2008). Backcrossing IR28 to Jericho white, a spontaneous white flowered mutant of the French commercial variety Languedoc, over seven generations produced a near homozygous line named Lov 9 (Tate and Searle, unpublished). However, the GBCA levels in the Lov 9 seed from plants grown in shade houses or field conditions ranged from $0.4-1.2 \%$, respectively (Tate and Searle, unpublished). These GBCA levels in Lov 9 seed were deemed too high for commercial release of the variety as a low toxin variety. Another strategy to develop a zero GBCA toxin common vetch variety was interspecies crosses of zero toxin species $V$. villosa and $V$. pannonica to common vetch but these resulted in embryo abortion and no viable hybrids were recovered (Searle, unpublished). Considering the limited success to date, other pathways to produce a zero-toxin common vetch variety are required.

\section{APPLICATION OF BIOTECHNOLOGY TO PRODUCE ZERO-TOXIN VETCH}

Applications of biotechnology have promised to accelerate crop improvement (Moose and Mumm, 2008). The emergence of genomics, transcriptomics, metabolomics, and proteomics data has led to the establishment of publicly available databases for most major crops. For example, the LIS - Legume Information System (Dash et al., 2015), and eFP browser (Patel et al., 2012; Hawkins et al., 2017) now contain data for legumes. By combining the information available in these databases with new bioinformatic tools, we now have the ability to dissect complex traits to determine the underlying gene architecture in a more comprehensive way. In 2018 , the $1.8 \mathrm{~Gb}$ common vetch genome and seed transcriptome sequencing projects were initiated at the University of Adelaide, Australia, opening the opportunity to determine the genetic basis of the vetch toxin accumulation. Using this transcriptome data, we could identify the genes involved in toxin production and in the future we could investigate their functions by overexpressing or mutating candidate genes. Moreover, we envisage that application of CRISPR-Cas (clustered regularly interspaced short palindromic repeats - Cas protein) genome editing to modify agronomically important traits in crops such as wheat, barley, rice, and tomato (Liu et al., 2017) will soon be applied to more challenging species including the common vetch. Using CRISPR-Cas genome editing, the nutritional profiles of many crops have been recently demonstrated. For example, in tomato, knocking down genes in the carotenoid metabolic pathway led to a 5-fold increase in lycopene (Li et al., 2018), and in rice, generating mutations in the starch branching enzyme (Berrens et al., 2017) genes increased amylose content by up to $25 \%$ and resistant starch to $9.8 \%$ (Sun et al., 2017). One of the most significant impacts of CRISPR-Cas genome editing is the potential improvement of a key trait in a commercially released cultivar within 6 months. In contrast conventional breeding of the trait may take 5-7 years to release the new cultivar. Importantly, it only takes one generation to obtain an edited plant using genome editing.

A major challenge in non-model plant systems like common vetch, is the delivery of transgenes such as CRISPR-Cas ribonuclear complex into plant cells and subsequent plant regeneration. Unlike crops such as rice and barley where the transformation and plant regeneration systems are standardized (Sahoo et al., 2011; Harwood, 2014), efficient transformation, and plant regeneration systems are lacking for common vetch (Ford et al., 2008). Unfortunately, common vetch's GBCA toxin level have lowered the priority for research and development of these necessary biotechnological tools - for example developing a transformation system. Further investment in common vetch is required to develop transformation and plant regeneration systems to facilitate the application of genome editing for trait improvement. 


\section{FUTURE WORK AND EXPECTATIONS}

The environmental benefits, the versatile growth habit, and the rich nutritional profile of common vetch make the legume an appealing crop to meet future protein food requirements for humans and animals while sustainably contributing to our agricultural system. However, the failure of conventional breeding to develop a zero-toxin common vetch variety requires a new strategy to be employed. The recent availability of new vetch genomic resources and tools for genome editing increase the likelihood of solving the vetch GBCA toxicity problem. To make this plausible, we suggest the following steps are important for vetch.

To solve the vetch GBCA toxicity, we suggest the following experiments should be prioritized:

1. Sequencing, assembling and annotating the genome.

2. Comparing gene expression by RNA-seq and undertake biochemical pathway analysis of differentially abundant genes across vetch cultivars and Vicia species that do not contain GBCA.

3. Identifying candidate GBCA detoxifying genes and undertake functional gene analysis.

4. Establishing an efficient transformation and plant regeneration system.

5. Applying CRISPR-Cas9 or gene expression cassettes of candidate gene(s) to manipulate gene expression levels.

6. Screening of zero-toxin vetch lines and testing in animal assays.

\section{REFERENCES}

Arese, P., Bosia, A., Naitana, A., Gaetani, S., D’aquino, M., and Gaetani, G. F. (1981). Effect of divicine and isouramil on red cell metabolism in normal and G6PD-deficient (Mediterranean variant) subjects. Possible role in the genesis of favism. Prog. Clin. Biol. Res. 55, 725-746.

Asgar, M. A., Fazilah, A., Huda, N., Bhat, R., and Karim, A. A. (2010). Nonmeat protein alternatives as meat extenders and meat analogs. Comprehen. Rev. Food Sci. Food Saf. 9, 513-529. doi: 10.1111/j.1541-4337.2010.00124.x

Aura, J. E., Carrión, Y., Estrelles, E., and Jorda, G. P. (2005). Plant economy of hunter-gatherer groups at the end of the last Ice Age: plant macroremains from the cave of Santa Maira (Alacant, Spain) ca. 12000-9000 BP. Veg. History Archaeobot. 14, 542-550. doi: 10.1007/s00334-005-0002-1

Berrens, R. V., Andrews, S., Spensberger, D., Santos, F., Dean, W., Gould, P., et al. (2017). An endosiRNA-based repression mechanism counteracts transposon activation during global DNA demethylation in embryonic stem cells. Cell Stem Cell 21, 694-703.

Bottini, E. (1973). Favism: current problems and investigations. J. Med. Genet. 10, 154-157. doi: 10.1136/jmg.10.2.154

Bünemann, E. K., Bongiorno, G., Bai, Z., Creamer, R. E., De Deyn, G., De Goede, R., et al. (2018). Soil quality-A critical review. Soil Biol. Biochem. 120, 105-125.

Caliskanturk, K. S., Gunay, D., and Sayar, S. (2017). In vitro evaluation of whole faba bean and its seed coat as a potential source of functional food components. Food Chem. 230, 182-188. doi: 10.1016/j.foodchem.2017.03.037

Collins, C. L., Henman, D. J., King, R. H., and Dunshea, F. R. (2002). Common vetch (Vicia sativa cv Morava) is an alternative protein source in pig diets. Asia Pac. J. Clin. Nutr. 11, S249-S249.

Crépon, K., Marget, P., Peyronnet, C., Carrouée, B., Arese, P., and Duc, G. (2010). Nutritional value of faba bean (Vicia faba L.) seeds for feed and food. Field Crops Res. 115, 329-339. doi: 10.1016/j.fcr.2009.09.016

Dash, S., Campbell, J. D., Cannon, E. K. S., Cleary, A. M., Huang, W., Kalberer, S. R., et al. (2015). Legume information system (LegumeInfo. org): a key component
Although the first three objectives above can be readily achieved, the last three could take many years to be accomplished due to the absence of a demonstrably routine in vitro transformation and regeneration system for vetch. Therefore, expertise from the plant tissue culture field will be invaluable to achieving objective four and ultimately the final goal.

\section{DATA AVAILABILITY STATEMENT}

The datasets generated for this study are available on request to the corresponding author.

\section{AUTHOR CONTRIBUTIONS}

$\mathrm{VN}$ and IS initially conceived the manuscript. All authors contributed to the writing and editing of the manuscript.

\section{ACKNOWLEDGMENTS}

We would like to thank the Hermon Slade Foundation and The University of Adelaide for the initial funding awarded to IS and VN, respectively. We also thank Jeremy Timmis for useful feedback and editing of the manuscript. This manuscript has been released as a pre-print at https://doi.org/10.1101/2020.02.11. 943324 (Nguyen et al., 2020).

of a set of federated data resources for the legume family. Nucleic Acids Res. 44, D1181-D1188.

Delaere, I. (1996). The Chemistry of Vicia sativa selection. Doctor of Philosophy, The University of Adelaide, Adelaide.

Dong, R., Shen, S. H., Jahufer, M. Z. Z., Dong, D. K., Luo, D., Zhou, Q., et al. (2019). Effect of genotype and environment on agronomical characters of common vetch (Vicia sativa L.). Genet. Resour. Crop Evol. 66, 1-13.

Enneking, D. (1995). The Toxicity of Vicia species and Their Utilization as Grain Legumes. NedlandsW. A: University ofWestern Australia.

Erskine, W., Smartt, J., and Muehlbauer, F. J. (1994). Mimicry of lentil and the domestication of common vetch and grass pea. Econ. Bot. 48, 326-332. doi: $10.1007 / \mathrm{bf} 02862334$

Farran, M. T., Uwayjan, M. G., Miski, A. M. A., Sleiman, F. T., Adada, F. A., Ashkarian, V. M., et al. (1995). Effect of feeding raw and treated common vetch seed (Vicia sativa) on the performance and egg quality parameters of laying hens. Poult. Sci. 74, 1630-1635. doi: 10.3382/ps.0741630

Ford, R., Maddeppungeng, A. M., and Taylor, P. W. J. (2008). Vetch. Compendium of Transgenic Crop Plants 3, 163-170.

Francis, C. M., Enneking, D., and El Moneim, A. M. A. (2000). "When and where will vetches have an impact as grain legumes?," in Linking Research and Marketing Opportunities for Pulses in the 21st Century, Ed. R. Knight (Berlin: Springer), 375-384. doi: 10.1007/978-94-011-4385-1_34

Harper, J. A., and Arscott, G. H. (1962). Toxicity of common and hairy vetch seed for poults and chicks. Poult. Sci. 41, 1968-1974. doi: 10.3382/ps.0411968

Harwood, W. A. (2014). "A protocol for high-throughput Agrobacteriummediated barley transformation," in Cereal Genomics, eds A. Furtado, and R. J. Henry (Berlin: Springer), 251-260. doi: 10.1007/978-1-62703-715-0_20

Hawkins, C., Caruana, J., Li, J., Zawora, C., Darwish, O., Wu, J., et al. (2017). An eFP browser for visualizing strawberry fruit and flower transcriptomes. Horticult. Res. 4:17029.

Henchion, M., Hayes, M., Mullen, A. M., Fenelon, M., and Tiwari, B. (2017). Future protein supply and demand: strategies and factors 
influencing a sustainable equilibrium. Foods 6:53. doi: 10.3390/foods607 0053

Huang, Y., Li, R., Coulter, J. A., Zhang, Z., and Nan, Z. (2019). Comparative grain chemical composition, ruminal degradation in vivo, and intestinal digestibility In Vitro of Vicia sativa L. Varieties Grown on the Tibetan Plateau. Animals 9:212. doi: 10.3390/ani9050212

Joint, W. H. O. (2007). Protein and Amino Acid Requirements in Human Nutrition. World health organization technical report series. Geneva: World Health Organization.

Kaya, A. A., Yörük, M., Esenbuga, N., Temelli, A., and Ekinci, Ö (2013). Retraction: The Effect of Raw and Processed Common Vetch Seed (Vicia sativa) Added to Diets of Laying Hens on Performance, Egg Quality, Blood Parameters and Liver Histopathology. J. Poult. Sci. 50, 228-236. doi: 10.2141/jpsa.0120013

Li, X., Wang, Y., Chen, S., Tian, H., Fu, D., Zhu, B., et al. (2018). Lycopene is enriched in tomato fruit by CRISPR/Cas9-mediated multiplex genome editing. Front. Plant Sci. 9:559. doi: 10.3389/fpls.2018.00559

Liu, X., Wu, S., Xu, J., Sui, C., and Wei, J. (2017). Application of CRISPR/Cas9 in plant biology. Acta Pharm. Sin. B 7, 292-302. doi: 10.1016/j.apsb.2017.01.002

Lobell, D. B., and Gourdji, S. M. (2012). The influence of climate change on global crop productivity. Plant Physiol. 160, 1686-1697.

Mao, Z., Fu, H., Nan, Z., and Wan, C. (2015). Fatty acid, amino acid, and mineral composition of four common vetch seeds on Qinghai-Tibetan plateau. Food Chemi. 171, 13-18. doi: 10.1016/j.foodchem.2014.08.090

Mba, W. P., Longandjo, G.-N. T., Moufouma-Okia, W., Bell, J.-P., James, R., Vondou, D. A., et al. (2018). Consequences of $1.5 \mathrm{C}$ and $2 \mathrm{C}$ global warming levels for temperature and precipitation changes over Central Africa. Environ. Res. Lett. 13:055011. doi: 10.1088/1748-9326/aab048

Mikić, A. (2016). Presence of vetches (Vicia spp.) in agricultural and wild floras of ancient Europe. Genet. Resour. Crop Evol. 63, 745-754. doi: 10.1007/s10722016-0382-3

Mikić, A., Mihailović, V., Karagić, Đ, Milošević, B., Milić, D., Vasiljević, S., et al. (2019). Common vetch (Vicia sativa) multi-podded mutants for enhanced commercial seed production. Proc. Appl. Bot. Genet. Breed. 180, 78-81. doi: 10.30901/2227-8834-2019-1-78-81

Moose, S. P., and Mumm, R. H. (2008). Molecular plant breeding as the foundation for 21st century crop improvement. Plant Physiol. 147, 969-977. doi: 10.1104/ pp.108.118232

Navrátilová, A., Neumann, P., and Macas, J. (2003). Karyotype analysis of four Vicia species using in situ hybridization with repetitive sequences. Ann. Bot. 91, 921-926. doi: 10.1093/aob/mcg099

Nguyen, V., Riley, S., Nagel, S., Fisk, I., and Searle, I. R. (2020). Common Vetch: a drought tolerant, high protein neglected leguminous crop with potential as a sustainable food source. bioRxiv [Preprint] doi: 10.1101/2020.02.11.943324

Patel, R. V., Nahal, H. K., Breit, R., and Provart, N. J. (2012). BAR expressolog identification: expression profile similarity ranking of homologous genes in plant species. Plant J. 71, 1038-1050. doi: 10.1111/j.1365-313x.2012.05055.x

Pfeffer, M., and Ressler, C. (1967). $\beta$-Cyanoalanine, an inhibitor of rat liver cystathionase. Biochem. Pharmacol. 16, 2299-2308. doi: 10.1016/00062952(67)90217-1

Rathjen, J. (1997). The Potential of Vicia sativa L. as a Grain Legume for South Australia. PhD thesis, University of Adelaide, Adelaide.
Reeves, D. W. (1997). The role of soil organic matter in maintaining soil quality in continuous cropping systems. Soil Tillage Res. 43, 131-167. doi: 10.1016/s01671987(97)00038-x

Ressler, C., Tatake, J. G., Kaizer, E., and Putnam, D. H. (1997). Neurotoxins in a vetch food: stability to cooking and removal of $\gamma$-glutamyl- $\beta$-cyanoalanine and $\beta$-cyanoalanine and acute toxicity from common vetch (Vicia sativa L.) legumes. J. Agricult. Food Chem. 45, 189-194. doi: 10.1021/jf9603745

Ritthausen, H., and Kreusler, U. (1870). Ueber Vorkommen von Amygdalin und eine neue dem Asparagin ähnliche Substanz in Wickensamen (Vicia sativa). J. Prak. Chem. 2, 333-338. doi: 10.1002/prac.18700020138

Roy, D. N., Sabri, M. I., Kayton, R. J., and Spencer, P. S. (1996). $\beta$-cyano-L-alanine toxicity: evidence for the involvement of an excitotoxic mechanism. Nat. Toxins 4, 247-253. doi: 10.1002/(sici)(1996)4:6<247::aid-nt1>3.0.co;2-m

Sahoo, K. K., Tripathi, A. K., Pareek, A., Sopory, S. K., and Singla-Pareek, S. L. (2011). An improved protocol for efficient transformation and regeneration of diverse indica rice cultivars. Plant Methods 7:49. doi: 10.1186/1746-4811-7-49

Sivakumar, M. V. K., Das, H. P., and Brunini, O. (2005). "Impacts of present and future climate variability and change on agriculture and forestry in the arid and semi-arid tropics," in Increasing Climate Variability and Change, eds J. Salinger, M. V. K. Sivakumar, and R. P. Motha (Berlin: Springer), 31-72. doi: 10.1007/1-4020-4166-7_4

Sun, Y., Jiao, G., Liu, Z., Zhang, X., Li, J., Guo, X., et al. (2017). Generation of highamylose rice through CRISPR/Cas9-mediated targeted mutagenesis of starch branching enzymes. Front. Plant Sci. 8:298. doi: 10.3389/fpls.2017.00298

Tate, M. E., and Enneking, D. (1992). A mess of red pottage. Nature 359, 357-358. doi: $10.1038 / 359357 \mathrm{a} 0$

Tate, M. E., Rathjen, J., Delaere, I., and Enneking, D. (1999). Covert trade in toxic vetch continues. Nature 400:207. doi: 10.1038/22198

Tenopala, J., González, F. J., and De La Barrera, E. (2012). Physiological responses of the green manure, Vicia sativa, to drought. Bot. Sci. 90, 263-285.

Valentine, S. C., and Bartsch, B. D. (1996). Production and composition of milk by dairy cows fed common vetch or lupin grain as protein supplements to a silage and pasture-based diet in early lactation. Aust. J. Exp. Agricult. 36, 633-636.

Westhoek, H., Rood, T., Van Den Berg, M., Janse, J., Nijdam, D., Reudink, M., et al. (2011). The protein puzzle: The Consumption and Production of Meat, Dairy and Fish in the European Union. The Hague: Netherlands Environmental Assessment Agency.

White, P., Harries, M., Seymour, M., and Burgess, P. (2005). Producing Pulses in the Northern Agricultural Region. Kensington: Western Australia Department of Agriculture and Food.

Conflict of Interest: The authors declare that the research was conducted in the absence of any commercial or financial relationships that could be construed as a potential conflict of interest.

Copyright (c) 2020 Nguyen, Riley, Nagel, Fisk and Searle. This is an open-access article distributed under the terms of the Creative Commons Attribution License (CC BY). The use, distribution or reproduction in other forums is permitted, provided the original author(s) and the copyright owner(s) are credited and that the original publication in this journal is cited, in accordance with accepted academic practice. No use, distribution or reproduction is permitted which does not comply with these terms. 